\title{
A short history of the $\mathbf{G}^{\text {out }}$
}

and the Rheumatic Diseases 



\section{the $G^{\text {out }}$ short history of}

and the Rheumatic Diseases

by W. S. G. Copeman, M.D., F.R.C.P.

There is a dead medical literature, and there is a live literature-

The dead is not all ancient, and the live is not all modern-

Oliver Wendell Holmes

UNIVERSITY OF CALIFORNIA PRESS

Berkeley and Los Angeles

1964 
University of California Press Berkeley and Los Angeles, California

Cambridge University Press

London, England

(C) 1964 by The Regents of the University of California Library of Congress Catalog Card Number: 64-16012

Printed in the United States of America 